\title{
An Archetypal Interpretation of Power Figure in Irish Murdoch's The Flight from the Enchanter
}

\author{
Lei Zhang ${ }^{1}$ \\ ${ }^{1}$ School of Foreign Language Studies, Dalian Jiaotong University, Dalian, Liaoning 116028, China \\ *Corresponding author. Email: leiiris@163.com
}

\begin{abstract}
When many other 20th century English novels focus on social documentary, Iris Murdoch attaches more concerns with an extraordinary reality: modern industry corrupts human beings' moral sensibility. This paper adopts myth and archetypal criticism as the base of research and probes into archetypal characters and classical themes and interprets Murdoch's metaphorical attention towards the meanings of existence and the lost identity of modern men.
\end{abstract}

Keywords: corrupt, moral sensibility, archetypal, lost identity

\section{INTRODUCTION}

No one knows when the myths and legends were created or by whom. But they have lived for more than three thousand years, and entered nearly all the literatures of modern world; even some of them are part of our daily thought and conversation. They are less destructible than men or nations. Even the religion of which they were once a part has perished and its temples are ruined, the myths live on, with the deathless youth go into modern life. Mythology becomes an essential appearance in many modern works. The twentieth century has witnessed many negative and evil results of modern civilization: the deepening social conflicts, the collapse of morality, the degradation of ideals and disintegration of beliefs. Therefore, people eagerly ask for solution and salvation. "Only myth, with its suggestion of an action that can contain the destinies of those who are contemplating it, can provide any hope or support at all" [1]. At the present time, the most interesting development of classical influence in modern thought is the reinterpretation and revitalization of the Greek myths and religious legends. This is going on in two different fields: one is almost wholly literary and mainly dramatic, and the other has produced a great deal of literature indirectly but is primarily psychological and philosophical[2].

In modern literature, a medium and a system of codes are provided by myths which have a broad and underlying cultural meaning and make it possible for novelists to employ a shorthand system of symbolic reflections on current events. In a great number of literary works a light of mythology glimmers. Contemporary writers not only draw on these cultural myths in literature in an attempt to rediscover their foundation of ancient myth. Furthermore, they are also myth-makers-as storytellers attempting to explain existence in human terms.

When at a time myth seems to be the most important and inclusive world in modern criticism, to discuss myth and mythmaking in contemporary writing is essential. Then Myth and Archetypal criticism appears, aiming at expressing recurring literary phenomena as motifs, themes, and even narrative designs, hoping to explain the structural principles behind those archetypal myths and legends in the stories and ceremonies among diverse cultures. Myths and archetypes thus offer the literary critic one more alternative to probe into modern human conditions.

Critics among this school believe: although distinctive mythology may differ from person to person, which may be reflected in legend, folklore and ideology, yet in general sense, myth is bound to be universal. What's more, similar themes or motifs may be found in a large number of different mythologies, and certain images which recur in bottom of heart of peoples who have their own myths and widely separated in time and place tend to share common meanings or more accurately, they elicit comparable psychological responses and to serve similar cultural functions. Such motifs and images are called archetypes [3]. The famous archetypal critic Jung adapts the term "collective unconsciousness" which is much more universal in nature as it represents the primordial types of man's primitive instincts. And this kind of collective thing can be represented by single separate archetype human beings are familiar with, in other words, there are as many archetypes as there are typical situation in life. 
Another famous myth critic, Northrop Frye, on the basis of Jung's research, establishes his archetypal criticism system. He regards literature as the recurrence of myths and legends and myth serves important role for the structure of modern literature. "The myth is the central informing power that gives archetypal significance to the ritual and archetypal narrative to the oracle" [1]. Meanwhile, Frye believes archetypes reappear in many literary fiction and remain steadily the same: "there is a single pattern of significance, out of which myth constructs a central narrative around a figure who is partly the sun, partly vegetative fertility and partly god or archetypal human being" [1]. Then the mythical powerthe tales of gods are the most basic pattern in literary works.

However, to recognize archetypes in specific work and paragraphs isn't an easy job, for literary works are displaced myths which have been revised. Those primitive myths and religious rituals may be transformed as patterns and gods hiding behind various characters. The description of protagonist's birth, adventure, triumph, suffering and death is no other than a repetition of the story of gods in myths. In a word, literary works are virtually telling the same myth stories or focusing on several parts in different ways and patterns.

Iris Murdoch, a gifted storyteller of a special kind, not only delights us with an abundance of sensuous details, finely observed and resourcefully invented, but also makes ideas come alive as she does so. She intends to mythicize everyday life in her distinctive way of storytelling, out of imaginary characters and dramatically exciting action come spiritual significance. Just as she has said: "in an age such as ours, where the world of religion has become completely problematic, there are psychological forces working loose, as it were, as if they were demons or spirits" [4]. So, the mythical is not something extra, we live in myth and symbol all the time.

Thus, Iris Murdoch in one of her major fiction The Flight from the Enchanter adds many mythical factors. Adopting an archetypal angle to analyze these images, symbols and mythical themes, the paper intends to interpret the artistic and moral pursuit in Murdoch's fictional world - from the enchantment through attention to the reality of good.

\section{OVERVIEW OF TARGET WORK AND MAIN CHARACTERS}

The Flight from the Enchanter, Iris Murdoch's second novel, is about the rootlessness caused by the Second World War. The story centers on the relationships of a school of characterks with a dominant "enchanter" figure, Mischa Fox. He is not easily fathomed. As a lord of a newspaper chain, he seems to be powerful mysteriously in both political and social spheres, exerts curious sexual attraction over women, and is very rich. We follow the fortunes of the three main characters: Rosa Keepe, John Rainborough and Annette Cockeyne. Rosa is a woman Mischa has loved and who has rejected him.
Rainborough is an ex-civil servant who holds an important post in the Special European Labour Immigration Board, better known as SELIB, an organization for the administration of the entry of refugees into the country. Annette is the daughter of one of Rosa's schoolmate who lives with Rosa. At the beginning of the novel, Annette decides that "from now on I shall educate myself, I shall go out into the school of life" [5]; Rainborough is being pursued by his typist Agnes Casement; Rosa is a fairly well-off, educated lady who works in a factory because of her idealistic Socialism, and is the mistress of the two Polish refugee co-workers, Kan and Stefan Lusiewicz, Rainborough and Rosa are menaced by Miss Casement and the Lusieuicz brothers; and both are ultimately rescued. The story describes a series of incidents connected to Mischa's attempt, with the help of his henchman, Calvin Blick, to manipulate a periodical the Artemis. The crisis of the book consists of two suicides, the real one of Nina, who is a dressmaker, a victim of Mischa's power, and the comical one of Annette's to end it all. Rosa, who has contemplated staying with Mischa after all, in driven by Calvin's report of Nina's suicide to return to resume her London life. Annette returns to her "free" life with her parents, traveling from country to country. Rainborough cuts free of his social and personal involvement, and accepts the refugee offered by Annette's mother, Marian Cockeyne. The Artemis remains in Rosa's hand, and she is seen at the end of the book to be taking an interest in this survival of her mother's suffragette and socialist faith, which she had earlier avoided. Mischa is last seen on the Mediterranean shore near his Italian villa with Calvin.

\section{DEMONIC POWER FIGURE AS ALIEN GOD}

God is the most well-known figure in The Bible of Christianity. He is worshiped by a lot of people all over the world and especially the Jews consider their God as powerful and mythical. He created the whole world, animated animals, plants as well as human beings. God is omniscient because he knows each and every action of the unlimited lives of all the unlimited soul of this universe. He gives this world love, truth, holiness, mercy, gentleness, righteousness, perfection, justice, faithfulness and grace, so he is a figure of supreme good and powerful. Long times ago, the endless illusive quality of God gives rise to so many new interpretations in many literary works and God himself becomes one of the most often borrowed biblical archetypes in modern literature. Nowadays, one of ways in which myths revive in modern literature is a total inheritance and improving development of symbolism and metaphor which characterize myth expression well. Murdoch in her The Flight from the Enchanter adopts a developed figure of God; she falsifies God and models an alien God in a demonic human world.

Richard Todd has pointed out that: The Flight from the Enchanter states clearly a particular kind of 
mythology[6]. In fact, on a mythical level, the world of The Flight from the Enchanter can readily been seen as a type of Northrop Frye's "demonic human world" which is described as "a society held together by a kind of molecular tension of egos, a loyalty to the group or the leader which diminishes the individual." [7] According to Frye, the human world is full of sins, and one individual pole is the tyrant-leader, who is inscrutable, ruthless, melancholy and with an insatiable will and he commands loyalty and represents the collective ego of those followers. The other pole is represented by sacrificed victim, to be killed to strengthen the others [7]. However, Murdoch portrays a figure like Frye's "most concentrated form of demonic parody" as the tyrant and the victim become one. Therefore, the figure who is elected, as it were, to be God by other people, and made into a god who is a kind of false God[6]. Then the title indicates the fact that: the main character Mischa acts at the same time two roles: the tyrant being worshiped by others as well as the victim himself. First of all, he is the enchanter, who is a source of great fantasy for all his London victims except Peter Saward. In the novel, they are proud of knowing him, pursue him eagerly, listen to his orders as to an oracle, obey him, and love him deeply. Mischa, with one eye blue and one brown, enslaves them partly through the devices of Calvin Blick, who is the "dark half of Mischa's mind." [5] The main action involves the struggle of characters to free themselves from the spell cast by the powerful central enchanter and refugee of the book. Mischa's real power lies in his ability to charm and churn the imaginations of others. His persona is at least partially a creation of his friend's imaginations, and realizing that, he enjoys his mystery and his ability to maneuver and observe their struggle. As he says to Annette: "I am not famous for anything in particular, I am just famous" [5]. Mischa sees himself or is perceived as being at the centre. Against this might be set Simone Weil's dictum that "Just as God, being outside the universe, is at the same time the centre, so each man imagines he is situated in the centre of the world. The illusion of perspective places him at the centre of space" [8]. For religious people, only God can be perceived as the controller of universe because he created the world and animated all living things. So, what Mischa wants to achieve here is to act as the God who is worshiped spiritually by plenty of pursuers and can give orders any time he likes even control and enchant others around him. He admires God and wants to learn from God the great sovereignty and dignity. However, God is of supreme goodness. He gives the world truth and reality. But Mischa, with vicious mind, intends to create a kind of fantasy to trap others and catch hold of their material and spiritual possession. Mischa's character as enchanter is created not only by what the reader knows from his authorial evidence but rather from the secondhand reports of others whose reports in turn are seldom first-hand. His power is never alluded to as earthly phenomena. Through Nina, we learn her complete submission to his will. She is ready from the first to be his slave, because "he bore with him the signs of a great authority and carried in his indefinable foreignness a kind of oriental magic"[5], and because "Mischa was supposed to have at his disposal dozens of enslaved beings of all kinds whom he controlled at his convenience" [5]. Rosa, when Mischa is concerned, is prepared to believe anything. When she feels that she has to go to Mischa for help after being distressed intolerably by the Lusiewicz brothers, she is "quite ready to acknowledge herself to be under a spell. She knew that even if at that moment Mischa were oblivious of her existence, yet he was drawing her all the same" [5]. Annette, seeing Mischa for the first time, feel she has to look into her own eyes, like "someone upon a high place who is only saved from vertigo by looking straight ahead" [5]; she desperately hunts for "some charm" against the incomprehensible pain of his presence. Meanwhile, Mischa' house also represents the prefabricated enchantment with Mischa holds other people. As James Gindin comments, "the house itself also reflects Mischa's personality, the labyrinthine quality that helps make him so mysterious and attractive to others" [5]. Mischa's big party in this house has been wrongly anticipated by all the characters, as a redemptive and sublime moment. "The confused nature of their hopes, their breathless expectations and their pride in being present are all unwarranted." [9] They assemble, glowing with excitement, as if for a holy moment. Mischa is an odd person. To some extent, he has certain quality like a God who can be worshiped by other people around him. He has that kind of magic power which leads others to obey him and being controlled under him. He can create something like fantasy in which every other one commits him to be a leader.

In fact, the mystery of Mischa centers round the inexplicable duality of his role as evil controller as well as the passive innocent, and his power is seen as an inextricable combination of these. His public-image of ruthless power magnate is in sharp contrast with his private self-image as lonely, melancholy lover of the world. He is seen twice at the edge of the sea, of which Annette is aware that he is terrified. He is seen against a world where there has been the suffering and violence of the war, and where love, human friendship, human contact seems to be dead or dying. In his confessional talks with Peter Saward he sees himself as a gentle sentimentalist who, in his God-like compassion and love for all creatures, occasionally needs to destroy in order to save: "if the God kills us, it is not for their sport but because we fill them with such an intolerable compassion, a sort of nausea." [5] Mischa sees power as protection, which paradoxically leads to destruction; he is forced to destroy what he protects, from chickens to "slaves", to women. He asks Peter: "do you ever feel... as if everything in the world needed your-protection? It is a terrible feeling. Everything - even this matchbox" [5]. When Mischa weeps in recalling incidents of his childhood, usually speckled with reminiscences of dead chickens and dead kittens, Peter Saward wonders: "what demon drove Mischa continually to uncover and to torture this strange region of sensibility - and as he did 
so he reflected yet again how strangely close to each other in this man lay the springs of cruelty and of pity" [5]. Although in his own mind, Mischa equates pity with love, he repeatedly asserts to Rainborough, "I love all creatures" [5]. For Murdoch, However, pity like cruelty is a parody of love because it denies the contingency and independent dignity of other people. It is his pity for Nina that makes him rescue her and induce her to become one of his creatures, and robs her of her freedom and identity until her only recourse is death. It is possible that he sees Nina, as she sees herself now of her suicide, intolerably oppressed by the senseless blackness, better dead. Even his elaborate theory of love, formulated in abstract, inhuman terms, is delivered from the height of his attempts as God-like theorizing. Quite ironically, while his aim is to create a free and real woman, his means to such an end is "by breaking her"[5]. The manipulation of Rosa to aid her self-revelation indicates Mischa's bad faith in seeing her as a thing, a subject being who needs to be coached on her way to self-discovery.

And although Mischa is seen as a rich mystery by the other characters, he lives in a dry world. Mischa's world is not a world in which others can live. His relations to other individuals are either those of pity, or those of destruction, he cannot meet them in love. But Rosa is a character who must persist in believing that there is sense in the ordinary business of human communication. She goes back to edit the Artemis, a "little independent thing." [5] which Mischa's impulse would be to grab and destroy, like the instinct to catch fish or butterflies. Rosa is last seen with Peter at the inconclusive ending of the novel, contemplating the photographs of Mischa's vanished world of order and innocence. This is a symbol of Mischa's past control over Rosa. Although she has fled from the enchanter, she is still in a demonic human world and can therefore never travel too far from the enchanter or his Minotaur. Her only weapon will be her perception, imagination, and the aid of her work on the Artemis, through which she can perhaps work towards selflessness and ward off the spells of fantasy.

\section{DEMONIC POWER LEADING TO ENCHANTMENT}

Thus, such is an alien God-Mischa on whom Murdoch animates at the nib of the pen but does indicate certain sophisticated ideas. The Second World War brings human world a great disaster. As a novelist, to certain extent a realist novelist, when speculating the modern novels, Murdoch wonders and states: "Our inability to imagine evil is a consequence of the dramatic and despite Hitler, optimistic picture of ourselves with which we work." [10] Thus, Murdoch herself tries to create and reflect this kind of imperfection in her own fictional world, and then Mischa was born at the time when human beings have lost their personal God and to worship another false God among the middle-class English society. From what I have done the analysis of this god-like figure, we can conclude that: he intends to affect to an unusually large extent the lives of other people by whom he is surrounded. There are a circle of characters such as Nina, Annette, Rosa in The Flight from the Enchanter and Martin in A Severed Head, who are more or less dangerously controlled by them. They are often referred to as the "alien God", exotic, mysterious, seemingly omnipotent men who appear to glow with an "oriental" magic who represent the forces at work in an ambiguous universe. In fact, Iris Murdoch calls them the power figures. After the terror of Hitler and the conclusive loss of belief in personal God, she inserts in her novels the theme of power and power-figure: "people forces rules on other people and other people like it. This is the important aspect of power very often that people want to admire somebody." [11] But why? The probable reason is that the disastrous war not only destroys material possession of people, but also ruins their spiritual realm. Destruction of homeland gives them mental rootlessness. Everyone seems to lose his belief and dares not look into the reality, which is horrible and frustrating. Everything seems dead and people become to doubt the meaning to be alive. Therefore, they begin to escape, to flee from the cruel reality and would rather live in fantasy.

\section{CONCLUSION}

Murdoch's imagistic prose aids her creation of the fantastic, symbolic quality of her work. The enchanter or power-figure manipulates the fantasies of victims who need a dominating figure to provide metaphysical meaning and dynamic tension to their otherwise vague drifting lives, and Murdoch's protagonists can redeem themselves only by discovering new ways to see reality through breaking the enchantment and resisting the false consolations of fantasy, which Murdoch defines as "the enemy" of that true imagination. What those "alien Gods" do in these two novels result from the tyrannical need to impose power on others in order that one might treat them as abstractions, symbols or objects, to be exact the spiritual masters. Thus, mentally controlled by demonic power, those innocent victims live a miserable life.

\section{REFERENCES}

[1] N. Frye, The Great Code: The Bible and Literature. London: Routledge \& Kegan Paul, 1982.

[2] G. Highet, "The Reinterpretation of the Myths." Literary Criticism and Myth. Ed. Robert A. Segal. New York \& London: Library of Congress Cataloging in Publication, 1996.

[3] G.L.Wilfred, A Handbook of Critical Approaches to Literature. London: Oxford University Press, 1992.

[4] D. J. Gordon, Iris Murdoch's Fables of Unselfing. Columbia and London: University of Missouri Press, 1995.

[5] I. Murdoch, The Flight from the Enchanter. London: Chatto\& Windus, 1956.

[6] R. Todd, Iris Murdoch. New York and London: Methuen Co. Ltd, 1984. 
[7] N. Frye, The Anatomy of Criticism. Princeton: Princeton University Press, 1990.

[8] P. J. Conradi, Iris Murdoch: the Saint and the Artist. London: The Macmillan Press, 1986.

[9] E. Dipple, Iris Murdoch: Work for the Spirit. London: Methuen, 1982.
[10] I. Murdoch, "Against Dryness." Iris Murdoch: Modern Critical Views. Ed. Harold Bloom. New York: Chelsea House Publishers, 1986.

[11] C. Bigsby, The Radical Imagination and the Liberal Tradition: Interviews with English and American Novelists. Ed. Heide Ziegler and Christopher Bigsby. London: Junction Books, 1982. 